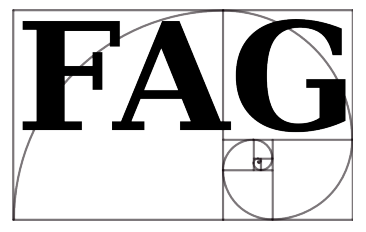

http://www.nauka-a-religia.uz.zgora.pl/images/FAG/2005-2006.t.2-3/art.11.pdf

\author{
Kazimierz Jodkowski
}

\title{
Klasyfikacja stanowisk kreacjonistycznych *
}

Według powszechnych przekonań istnieje tylko jedno stanowisko kreacjonistyczne. Kreacjonistą według tego przekonania jest ktoś, kto odrzuca teorię ewolucji, kto ze względów religijnych (najczęściej „sekciarskich”, tzn. wyznawanych przez mniejszościowe wyznania, głównie protestanckie) ,nie wierzy w Darwina”, kto dosłownie traktuje znajdowany w Biblii opis stworzenia świata, a w Ameryce próbuje nawet zastąpić w programach szkolnych nauczanie ewolucjonizmu przez nauczanie kreacjonizmu. Kreacjonizm tak rozumiany jest poglądem dziwacznym, wstecznym, nienaukowym, a kreacjoniści mylą naukę z religią i właściwie nie wiadomo, czego chcą. Bo czego można nauczać na proponowanych przez nich lekcjach kreacjonizmu - ciągle powtarzać, że Bóg stworzył świat i życie? ${ }^{1}$

Przy bliższym jednak przyjrzeniu się ruchowi kreacjonistycznemu okazuje się, że istnieje w nim wiele stanowisk i poglądów, często nawet wzajemnie, co do pewnych twierdzeń, sprzecznych. A także - że kreacjoniści różnych orientacji niejednokrotnie równie zaciekle zwalczają się wzajemnie, co krytykują ewolucjonizm. Niektóre z tych

\footnotetext{
* Recenzent: Zbysław MuszyŃski, Zakład Logiki i Metodologii Nauk UMCS, Lublin.

${ }^{1}$ „Załóżmy jednak, że zamierzamy nauczać kreacjonizmu. Co będzie przedmiotem nauczania? Jedynie to, że Stwórca powołał do istnienia gotowy wszechświat i wszystkie gatunki? Tylko tyle? Nic więcej? Żadnych szczegółów?" (Isaak Asımov, Blądzący umysł, Pandora, Łódź 1995, s. 26).
} 
orientacji są wyraźnie nazywane i identyfikowane przez samych kreacjonistów lub ich krytyków, ale tylko niektóre. Najczęściej spotykane określenia to kreacjonizm biblijny i kreacjonizm naukowy oraz kreacjonizm starej i młodej Ziemi. Różnic istnieje jednak dużo więcej i można pokusić się o ich klasyfikację, a jeśli to niemożliwe, to przynajmniej o uporządkowanie. Próby takie są nieliczne w literaturze przedmiotu. Poniżej omówię kilka najbardziej znanych, wskazując na ich wady lub niekompletny charakter, aby zakończyć własną klasyfikacją wolną od wspomnianych wad. Zarzut niekompletności do pewnego stopnia jest jednak arbitralny, trzeba bowiem zdecydować się, co się rozumie przez kreacjonizm. W poniższych analizach przyjmę rozumienie najszersze, etymologiczne - kreacjonizm to pogląd, że co najmniej życie i człowiek, a może także Wszechświat, są wynikiem stworzenia przez wcześniej istniejącą inteligencję. Tak rozumiany kreacjonizm może, ale nie musi, być niezgodny z ewolucjonizmem, czyli poglądem o wspólnocie pochodzenia (istniejące obecnie formy życia pochodzą od wspólnego przodka bądź - jak niektórzy chcą od niedawna ${ }^{2}-$ od grupy wspólnych przodków).

\section{Podział Millarda J. Ericksona ${ }^{3}$}

Erickson wyróżnił pięć stanowisk, dotyczących pochodzenia życia, z których cztery mają charakter kreacjonistyczny w określonym powyżej sensie.

\footnotetext{
${ }^{2}$ Por. Carl Woese, „A New Biology for a New Century”, Microbiology and Molecular Biology Reviews June 2004 (za: Freeman Dyson, „The Darwinian Interlude”, Technology Review February 4, 2005; http://www.technologyreview.com/articles/05/03/issue/magaphone. asp?trk=nl).

${ }^{3}$ Millard J. Erickson, Christian Theology, Baker, Grand Rapids, MI 1985, s. 478-484 (tlum. polskie: Millard J. Erickson, „Pięć modeli pochodzenia człowieka”, Na Początku... 1997, nr 6 (87), s. 125-132).
} 


\section{A. Stanowiska}

\section{a) Ewolucjonizm naturalistyczny}

Jest to stanowisko niekreacjonistyczne. Wyjaśnia ono pochodzenia człowieka, jak też innych form życia, bez odwoływania się do czynnika nadprzyrodzonego. Wszystko, co istnieje, jest wynikiem działania procesów przyrodniczych, bez ingerencji istoty boskiej. Procesy przyrodnicze mają charakter przypadkowy, przynajmniej do powstania życia. Od tego momentu działa deterministycznie dobór naturalny, który spośród rozmaitych mutacji, pożytecznych, szkodliwych i neutralnych, wyławia te, które umożliwiają organizmowi przetrwanie. Organizmy żywe są niezwykle skomplikowane i zdolne do licznych czynności, ale nie dlatego, że zaplanował je i stworzył ktoś rozumny.

\section{b) Deistyczny ewolucjonizm}

Jest to pogląd kreacjonistyczny najmniej odbiegający od przyjmowanego w nauce ewolucjonizmu naturalistycznego. Bóg stworzył pierwszą materię nadając jej prawa, ale potem wycofał się z aktywnej działalności w świecie. W tym ujęciu można mówić, że Bóg jest stwórcą wszystkiego, ale tylko pośrednio, za pośrednictwem tzw. przyczyn wtórnych. Bóg jest tu przyczyną pierwszą, ostateczną, a ewolucja jest narzędziem. Deistyczny ewolucjonizm, za wyjątkiem poglądu o samym początku istnienia materii, jest identyczny $\mathrm{z}$ naturalistycznym ewolucjonizmem. Zaprzecza bowiem, by w trakcie procesu ewolucyjnego Bóg bezpośrednio działał, zmieniając jego naturalny kierunek.

Erickson jako jeden $\mathrm{z}$ nielicznych wypowiada niezwykle trafną tezę, że ewolucjonizm deistyczny jest najlepszym sposobem opisania tego, co powszechnie (i błędnie) nazywa się ewolucjonizmem teistycznym (bądź - dodajmy określenie występujące w polskiej literaturze przedmiotu - kreacjonizmem ewolucyjnym). 


\section{c) Teistyczny ewolucjonizm}

Ta odmiana kreacjonizmu różni się od poprzedniej tym, że oprócz pierwotnej bezpośredniej aktywności Boga dopuszcza także okazyjnie jego interwencje w późniejszym okresie. Działał on albo modyfikująco - używając istniejącego już materiału, albo tworząc coś na nowo, na przykład ludzką duszę. Teistyczny ewolucjonizm programowo nie sprzeciwia się danym osiągniętym w naukach przyrodniczych. W pełni zgadza się z poglądem, że fizyczny wymiar człowieka, jego ciało, powstało w procesie ewolucyjnym.

\section{d) Kreacjonizm progresywny}

Ta forma kreacjonizmu wprowadza więcej elementów bezpośredniej aktywności Boga. Nie wyklucza działania ewolucji, ale uważa, że proces ewolucyjny nie jest w stanie utworzyć całego bogactwa form życia. Bóg musiał od czasu do czasu działać bezpośrednio w przyrodzie: albo modyfikująco, albo tworząc na nowo pewne cechy, organy czy nawet całe organizmy. W ten ostatni sposób, czyli de novo, powstał człowiek - zarówno jego natura fizyczna, jak i duchowa. Ale wiele innych gatunków mogło powstać ewolucyjnie z pierwotnych rodzajów (w biblijnym, odmiennym od naukowego sensie słowa „rodzaj”), bowiem „dzień” z biblijnego opisu stworzenia można rozumieć jako odnoszący się do długich okresów czasu.

\section{e) Kreacjonizm typu fiat}

Według tej, najbardziej skrajnej postaci kreacjonizmu, Bóg w krótkim czasie (np. tygodnia) działając bezpośrednio doprowadził do zaistnienia niemal wszystkiego, co istnieje obecnie. Nowe gatunki powstały nie jako modyfikacje już wcześniej istniejących, ale były specjalnie stworzone przez Boga. Każdy gatunek jest całkowicie odrębny od innych. Kreacjonizm typu fiat jest najbardziej zgodny z dosłownym odczytaniem biblijnego opisu stworzenia, ale najmniej $-\mathrm{z}$ dostępnym materiałem naukowym. 


\section{B. Wady podziału}

Podstawową wadą podziału Ericksona jest brak rozróżnienia kreacjonizmu biblijnego i naukowego. Wprawdzie niektórzy antykreacjoniści uważają, że rozróżnienie to jest fikcyjne, czyli że wszyscy kreacjoniści to kreacjoniści biblijni, tylko niektórzy się do tego nie przyznają, ale poglądu tego nie da się utrzymać. Rozróżnienie to można przeprowadzić na gruncie metodologicznym, odwołując się do odmiennych sposobów uzasadniania twierdzeń, w związku z czym nie ma podstaw, by nie wierzyć w tej sprawie kreacjonistom.

Drugą wadą podziału Ericksona jest brak rozróżnienia na kreacjonizm starej i młodej Ziemi. Erickson utożsamia ten pierwszy z kreacjonizmem progresywnym, a drugi z kreacjonizmem typu fiat, ale utożsamienie to nie jest żadną koniecznością i niezgodne jest $\mathrm{z}$ faktycznym występowaniem takich odmian kreacjonizmu, według których Wszechświat i Ziemia są stare, ale Bóg działał w sensie fiat. Sam Ericson zresztą wprowadza zamieszanie do swojego podziału twierdząc, że wg progresywnego kreacjonizmu akty stwórcze Boga miały też czasami charakter fiat. ${ }^{4}$

\section{Klasyfikacja Eugenie Scott i Donalda Wise’a}

Oboje tych autorów do przeprowadzenia klasyfikacji wybierało stopniowalne cechy: Scott - stopień dosłownej interpretacji biblijnego opisu stworzenia, ${ }^{5}$ natomiast Wise - łącznie dosłowność interpretacji oraz stopień sprawowanej przez Boga kontroli we Wszechświecie. ${ }^{6}$

\footnotetext{
${ }^{4}$ Por. Stephen E. Jones, „Komentarz do typologii Ericksona”, Na Początku... 1997, nr 6 (87), s. 132-135.

${ }^{5}$ Por. Eugenie C. Sсотт, „The Creation/Evolution Continuum”, National Center for Science Education Reports 1999, vol. 19, no. 4, s. 16-17, 23-25, http://www.natcenscied.org/ resources/articles/1593_the_creationevolution_continu_12_7_2000.asp (16 kwietnia 2006).

${ }^{6}$ Por. Donald U. WISE, „Creationism's Propaganda Assault on Deep Time and Evolution”, Journal of Geoscience Education 2001, vol. 49, no. 1, s. 30-35.
} 
Obie klasyfikacje są zbieżne i można potraktować je łącznie w postaci słupka stanowisk, w którym z góry na dół maleje stopień zaangażowania po stronie Biblii, natomiast rośnie stopień zaangażowania po stronie nauki:

\author{
płaskoziemcy \\ geocentryści \\ kreacjoniści młodej Ziemi \\ kreacjoniści starej Ziemi \\ kreacjoniści teorii luki czasowej \\ kreacjoniści konkordyzmu \\ progresywni kreacjoniści \\ kreacjoniści teorii inteligentnego projektu \\ kreacjoniści ewolucyjni \\ teistyczni ewolucjoniści \\ materialistyczni ewolucjoniści
}

\title{
A. Stanowiska
}

\section{a) Płaskoziemcy i geocentryści}

Obie te kategorie występują jedynie w klasyfikacji Eugenie C. Scott, Wise zaczyna swą klasyfikację od kreacjonistów młodej Ziemi. Scott uważa członków Towarzystwa Płaskiej Ziemi za zwolenników najbardziej skrajnej biblijnej literalistycznej teologii i zapewnia, że przewodniczący tego towarzystwa traktuje swoje poglądy bardzo poważnie. Ta opinia jest, niestety, niewiarygodna. Scott niepotrzebnie wmawia swoim czytelnikom istnienie dzisiaj towarzystwa płaskoziemców jako czegoś więcej niż organizacji złożonej z kawalarzy, bo obniża to rangę jej publikacji. Nie ulega wątpliwości, że w starożytnych kulturach Mezopotamii i Egiptu wierzono w płaską Ziemię, 
ale dyskusyjne już jest, czy ten pogląd jest wyrażony w Biblii. ${ }^{7} \mathrm{~W}$ każdym razie już $\mathrm{w}$ starożytności powszechnie wierzono $\mathrm{w}$ kulistą Ziemię. Wiara w płaską Ziemię w średniowieczu jest mitem, a co dopiero w czasach nowożytnych czy współczesnych. ${ }^{8}$

W przeciwieństwie do płaskoziemców geocentryści są zjawiskiem realnym we współczesnych ruchu kreacjonistycznym. Występują jednak w ,śladowych ilościach”. Sama Eugenie Scott nie była w stanie podać ani jednej ich publikacji. ${ }^{9}$ Najbardziej znanym dzisiaj geocentrystą jest dr Gerardus Bouw, profesor na Wydziale Matematyki i Nauk Komputerowych Baldwin-Wallace College w Berei, w stanie Ohio. ${ }^{10}$ Stopień doktora astronomii zdobył na dobrym amerykańskim uniwersytecie, Case Western Reserve University, nie można więc powiedzieć, że jego geocentryzm jest wynikiem nieuctwa. Bouw jest założycielem i dyrektorem Stowarzyszenia Biblijnej Astronomii oraz redaktorem czasopisma Biblical Astronomer. Aby odróżniać swoje poglądy od starożytnego geocentryzmu, Bouw ukuł nowy termin - geocentryczność. ${ }^{11}$ Współcześni geocentryści oprócz argumentów biblij-

\footnotetext{
${ }^{7}$ Por. dla przykładu: Paul H. Seely, „The geographic meaning of 'Earth' and 'Seas' in Genesis 1:10", Westminster Theological Journal 1997, vol. 59, no. 2, s. 231-256; James Patrick Holding, „Is the "erets (earth) flat? Equivocal language in the geography of Genesis 1 and the Old Testament: a response to Paul H. Seely", Creation Ex Nihilo Technical Journal 2000, vol. 14, no. 3, s. 51-54; Paul H. Seely, „Is the “erets (earth) flat?”, Creation Ex Nihilo Technical Journal 2001, vol. 15, no. 2, s. $52-53$ (odpowiedź Holdinga tamże, s. 53); Paul H. SeELY, „Is the word 'earth' ('eretz) equivocal?”, TJ 2002, vol. 16, no. 2, s. 73-76 (odpowiedź Holdinga tamże, s. 76-79).

${ }^{8} \mathrm{Z}$ mitem tym rozprawił się Jeffrey Burton Russell, Inventing the Flat Earth: Columbus and Modern Historians, Praeger Paperback, Westport 1997. Thomas Kuhn (Przewrót kopernikański, PWN, Warszawa 1966, s. 166-167) podaje nazwiska jedynych dwóch autorów, którzy sprzeciwiali się idei kulistości Ziemi. Jednym był Laktancjusz, żyjący na początku IV stulecia, a drugim - aleksandryjski mnich Kosmas, z połowy VI wieku. A więc płaskoziemcy byli wyjątkami nawet na przełomie starożytności i wczesnego średniowiecza.

${ }^{9}$ Dokładniej: w tekście głównym wymienia publikację Kaufmann 1985, ale w bibliografii brak tej pozycji.

${ }^{10} \mathrm{http}: / /$ homepages.bw.edu/ gbouw/

${ }^{11}$ Por. Gerardus D. Bouw, Geocentricity, Association for Biblical Astronomy, Cleveland 1992. Kreacjonistyczną krytykę poglądów Bouwa por. w artykule Danny’ego R. FAuLKNeRA,
} 
nych, które odgrywają dla nich pierwszorzędną rolę, odwołują się też do eksperymentów nieznanych w starożytności, jak eksperyment Michelsona-Morleya, Sagnaca, Michelsona-Gale'a czy tzw. niepowodzenie Airy'ego.

\section{b) Kreacjonizm młodej Ziemi}

Kreacjoniści młodej Ziemi w ujęciu Scott i Wise'a to kreacjoniści typu fiat wg podziału Ericsona.

\section{c) Odmiany kreacjonizmu starej Ziemi}

Wg Eugenie C. Scott i Donalda Wise'a kreacjonizm starej Ziemi występuje w kilku odmianach. Najbardziej biblijną odmianą jest kreacjonizm teorii luki czasowej. Według tej teorii między stworzeniem nieba i ziemi, o czym mówi pierwszy wiersz Księgi Rodzaju, a tym, o czym mówi wiersz drugi (,ziemia była bezładem i pustkowiem: ciemność nad powierzchnią bezmiaru wód") musiała zaistnieć długa luka czasowa, w trakcie której miał miejsce bunt części aniołów pod wodzą Lucyfera. Wojna z buntownikami doprowadziła do olbrzymich zniszczeń, po których nastąpiło opisane w Biblii odnowienie Ziemi w ciągu sześciu dni i stworzenie Adama i Ewy.

Zwolennicy teorii przerwy czasowej twierdzą, że sugerowało ją już kilku autorów starożytnych. ${ }^{12}$ Według informacji zawartych w ich pu-

\footnotetext{
„Geocentrism and Creation”, TJ 2001, vol. 15, no. 2, s. 110-121, który sprowokował wymianę zdań: Malcolm Bowden, „A geocentrist replies to 'Geocentrism and Creation'”, TJ 2002, vol. 16, no. 2, s. 79-81; „Danny Faulkner replies”, tamże, s. 81-82). Por. też Marshall HaLl, The Earth is not Moving, Fair Education Foundation, Cornelia, Georgia 1991 oraz krytyczną kreacjonistyczną jej recenzję: Danny FaULKNER, „Geocentric gobbledegook”, TJ 2001, vol. 15 , no. 2 , s. $36-37$.

${ }^{12}$ Por. Arthur C. Custance, Without Form and Void: A Study of the Meaning of Genesis 1:2, Dorway Press, Brockville, Ontario 1970; por. też Henry M. Morris, History of Modern Creationism, Institute for Creation Research, Santee, California 1993, s. 46 ods. 2; Mario Seiglie, Creation or Evolution. Does It Really Matter What You Believe?, United
} 
blikacjach, najstarsze znane stanowisko tego rodzaju należy przypisać żydowskim mędrcom $\mathrm{z}$ drugiego stulecia. Uczeni hebrajscy, którzy napisali Targum z Onkelos, najstarszą z aramejskich wersji Starego Testamentu, przetłumaczyli Ks. Rodzaju 1:2 jako ,i ziemia została położona pustkowiem". Język oryginału skłonił ich do przekonania, że nastąpiło coś, co „położyło pustkowiem” ziemię i to coś interpretowali jako zniszczenie. Podobnie miał interpretować ten fragment Orygenes (186-254) w komentarzu De Principiis ${ }^{13}$ oraz średniowieczny uczony flamandzki, Hugon od św. Wiktora (1097-1141): ,jak długo świat pozostawał w tym nieporządku, zanim regularne ponowne porządkowanie [...] go nie miało miejsca?". ${ }^{14} \mathrm{O}$ istnieniu luki czasowej między Rodz. 1:1 i 1:2 byli przekonani też inni średniowieczni uczeni jak Dionizy Peavius i Pererius. Według The New Schaff-Herzog Encyclopedia of Religious Knowledge ${ }^{15}$ holenderski uczony, Simon Episcopius (1583-1643), nauczał, że ziemia została pierwotnie stworzona przed sześcioma dniami stworzenia opisanymi w Ks. Rodzaju. Wszystkie te przykłady przytaczane przez zwolenników teorii przerwy czasowej mają służyć obaleniu przekonania, że teorię tę sformułowano w rozpaczliwej próbie pogodzenia nowożytnych danych geologicznych z zapisem biblijnym.

Teorię przerwy czasowej po raz pierwszy w czasach nowożytnych zaproponował Thomas Chalmers (1780-1847) w roku 1814, założyciel Wolnego Kościoła Szkocji (Free Church of Scotland). Spopularyzowana została ${ }^{16}$ przez znaną wówczas książkę George'a H. Pembera

Church of God 2000, s. 29 oraz Noel Hornor, Is the Bible True?, United Church of God 1998, s. 6-7.

${ }^{13}$ Ante-Nicene Fathers, Christian Literature Publishing Co., Buffalo 1917, s. 342; cyt. za: Seigle, Creation or Evolution..., s. 29 oraz Hornor, Is the Bible..., s. 7.

${ }^{14}$ De Sacramentis Christianae Fidei, Księga 1, Część I, Rozdział VI, cyt. za: Seiglie, Creation or Evolution..., s. 29 oraz HoRnOR, Is the Bible..., s. 7.

${ }^{15}$ The New Schaff-Herzog Encyclopedia of Religious Knowledge, Baker Book House, Grand Rapids 1952, vol. 3, s. 302.

${ }^{16}$ Por. John Rendle-Short, „Evolution - A Christian Option? Part 1. The 19th Century Ferment”, Creation Ex Nihilo, December 1987 - February 1988, vol. 10, No. 1, s. 47-48 [46- 
Earth's Earliest Ages z roku 1885, ${ }^{17}$ przez wiele książek wydanych przez Braci z Plymouth, a zwłaszcza w tzw. Biblii Scofielda (Scofield Reference Bible) w 1909 roku w postaci przypisów towarzyszących pierwszemu rozdziałowi Księgi Rodzaju, najpełniej w wydaniu z 1917 roku, w późniejszych została znacznie skrócona. ${ }^{18}$ Do najbardziej znanych XX-wiecznych zwolenników teorii przerwy czasowej należą Arthur C. Custance ${ }^{19}$ oraz George DeHoff ${ }^{20}$ i John Clayton. ${ }^{21} \mathrm{Wy}-$ stępuje ona w wielu wersjach, także w takiej, wedle której po znanych z geologii epokach nastąpił ok. 6 tysięcy lat temu kataklizm związany ze strąceniem Szatana z nieba.

Teoria przerwy czasowej ma niewielu zwolenników wśród kreacjonistów.

Inną odmianą kreacjonizmu starej Ziemi jest konkordyzm (DayAge Theory). Według tego ujęcia dzień biblijny z tygodnia stworzenia symbolizuje całe epoki, trwające tysiące albo miliony lat - zwolennicy przedstawiają argumenty, że tak też można interpretować termin „dzień”, występujący w Biblii. Zwolennicy konkordyzmu uważają, że istnieje paralela między tym, co mówi nauka i co opisuje Biblia,

48]; Herman BAvinck, In the Beginning: Foundations of Creation Theology, Ed. by John Bolt, Translated by John Vriend, Baker, Grand Rapids 1999, s. 116; Bernard L. RAmm, The Christian View of Science and Scripture, Paternoster, London 1955 (wyd. 1967), s. 196200; Roland L. Numbers, The Creationists. The Evolution of Scientific Creationism, Alfred A. Knopf, New York 1992 (University of California Press, Berkeley - Los Angeles - London 1993), s. 66-68.

${ }^{17}$ Bert Thompson podaje, że książka Pembera ukazała się w 1876 roku (por. Bert Thompson, „Popular Compromises of Creation - The Gap Theory”, Reason \& Revelation 1994, vol. 14, no. 7, s. 51 [49-56]).

${ }^{18}$ Por. C.I. Scofield, The Scofield Reference Bible, Oxford University, New York 1945, s. 3-4 (cyt. za: Hugh Ross, "Closing the Gap. A Scientist's Response to the Gap Theory", Facts for Faith Quarter 1 - 2001, Issue 5, s. 35 [28-35]).

${ }^{19}$ Custance, Without Form...

${ }^{20}$ George W. DeHoff, Why We Believe the Bible, DeHoff, Murfreesboro, TN 1944.

${ }^{21}$ John N. Clayton, The Source: Eternal Design or Infinite Accident?, wyd. przez autora, South Bend, IN 1976. 
zwłaszcza jeśli chodzi o kolejność pojawiania się na Ziemi roślin i zwierząt.

Większość kreacjonistów starej Ziemi to jednak tzw. progresywni kreacjoniści, czyli tacy kreacjoniści, którzy nie mają zastrzeżeń do naukowych metod wyznaczania wieku Ziemi i Wszechświata, ale uważają, że darwinowski mechanizm rozwoju form życia - mutacje i dobór - nie wystarcza do wyjaśnienia pojawienia się wszystkich tych form. Bóg, ich zdaniem, od czasu do czasu wkraczał ze swoimi aktami stwórczymi, stwarzając nowe rodzaje w biblijnym sensie tego słowa. Te rodzaje odpowiadają mniej więcej rodzinie w tradycyjnej taksonomii. Progresywni kreacjoniści dopuszczają istnienie ewolucji w ramach stworzonych typów, np. w rodzaju kota wskutek działania praw przyrody (czyli procesów mikroewolucyjnych) pojawiły się tygrysy, lwy, leopardy, pumy, koty domowe itd. Najbardziej znanym kreacjonistą progresywnym jest dr Hugh Ross, astronom ze stopniem doktora z Uniwersytetu w Toronto, który jednak nie praktykuje w astronomii, lecz zajmuje się prowadzeniem małej społeczności religijnej w Kalifornii i szefuje organizacji apologetycznej Reasons to Believe. ${ }^{22}$

Ostatnią odmianą kreacjonizmu starej Ziemi w wymienionej klasyfikacji jest teoria inteligentnego projektu. Argumenty z projektu były wykorzystywane od dawna, jeszcze przez kreacjonistów przeddarwinowskich, np. przez Paleya, który uważał, że istnienie Boga można wykazać przy pomocy jego dzieł. To Paley jest autorem słynnej analogii z zegarem: jak znaleziony zegar świadczy o istnieniu zegarmistrza, tak (a raczej: tym bardziej) istnienie roślin i zwierząt

\footnotetext{
${ }^{22}$ Najbardziej znane prace Hugh Rossa to Creation and Time. A Biblical and Scientific Perspective on the Creation-Date Controversy, NavPress, Colorado Springs 1994; The Creator and the Cosmos, NavPress, Colorado Springs 1993; The Fingerprint of God, Promise Publishing Co., Orange, CA 1991; Genesis One: A Scientific Perspective, revised edition, Wiseman Productions, Sierra Madre, CA 1983; Beyond the Cosmos, NavPress 1996 (revised edition 1999); A Matter of Days. Resolving a Creation Controversy, NavPress 2004; The Genesis Question: Scientific Advances and the Accuracy of Gnesis, NavPress 1998 (revised edition 2001); Fazale Rana \& Hugh Ross, Origins of Life: Biblical and Evolutionary Models Face Off, NavPress 2004; Fazale Rana with Hugh Ross, Who was Adam? A Creation Model Approach to the Origin of Man, NavPress 2005.
} 
świadczyć ma o istnieniu boskiego projektanta. Paley podobnie wnioskował, analizując budowę oka kręgowców. Dzisiejsi zwolennicy rozpoznawania $\mathrm{w}$ świecie przyrody inteligentnego projektu wychodzą raczej z wiedzy na temat struktury i funkcjonowania komórki. Najbardziej znany ich argument został przedstawiony przez biochemika, Michaela J. Behe'ego: niektóre układy biochemiczne, jak wić bakteryjna, kaskada krzepnięcia krwi, procesy biochemiczne zachodzące w trakcie widzenia itp., są nieredukowalnie złożone. Znaczy to, że usunięcie choćby jednej części z tych układów powoduje, że stają się one niefunkcjonalne. Tymczasem - twierdzi Behe - darwinowski ewolucjonizm wymaga, aby struktury takie powstawały stopniowo, w procesie zwanym kumulatywną ewolucją. Jeśli jednak - wnioskuje Behe - układy o mniejszej liczbie części są niefunkcjonalne, znaczy to, że nie powstały na drodze, o której mówią darwinowscy ewolucjoniści.

Argumenty Behe'ego zostały przez darwinistów potraktowane poważnie i doczekały się szczegółowej krytyki. ${ }^{23}$

Drugim „wynalazkiem” propagowanym przez zwolenników teorii inteligentnego projektu jest tzw. filtr eksplanacyjny - narzędzie służące do wykrywania projektu w przyrodzie. ${ }^{24}$ Polega ono na serii py-

${ }^{23}$ Por. na przykład: H. Allen OrR, „Ponownie darwinizm kontra inteligentny projekt”, Filozoficzne Aspekty Genezy 2004, t. 1, s. 33-48; Jerry A. Coyne, „Nowa fala fanatyzmu w nauce”, Filozoficzne Aspekty Genezy 2004, t. 1, s. 49-53; Russell F. Doolitle, „Subtelna równowaga”, Filozoficzne Aspekty Genezy 2004, t. 1, s. 55-64; Douglas J. Futuyma, „Cuda a molekuły”, Filozoficzne Aspekty Genezy 2004, t. 1, s. 65-70; Kenneth MiLler, „Odpowiedź na biochemiczny argument z projektu”, Filozoficzne Aspekty Genezy 2005. Wszystkie te teksty znajdują się na stronie http://www.nauka-a-religia.uz.zgora.pl/index.php?action=czasopismo

${ }^{24}$ Koncepcję filtra eksplanacyjnego sformułował William Dembski (por. William A. Dembsкi, The Design Inference. Eliminating Chance Through Small Probabilities, Cambridge University Press, Cambridge, UK - New York 1998, s. 36-47; William A. Dembski, „Redesigning Science”, w: William A. Dembsкi (ed.), Mere Creation. Science, Faith \& Intelligent Design, InterVarsity Press, Downers Grove, Illinois 1998, s. 98-104 [93-112]; William A. Dembsкi, Intelligent Design. The Bridge Between Science \& Theology, InterVarsity Press, Downers Grove, Illinois 1999, s. 133-134; William A. Dembski, „The Third Mode of Explanation: Detecting Evidence of Intelligent Design in the Sciences", w: Michael J. Behe, William A. Dembski, Stephen C. Meyer, Science and Evidence for Design in the 
tań i odpowiedzi. Po pierwsze, jeśli zjawisko nie jest przypadkowe, wyjaśniamy jego pojawienie się przez prawo kauzalne (konieczność). Jeśli jest przypadkowe, to pytamy o jego złożoność. Zjawisko przypadkowe o niewielkiej złożoności jest wielce prawdopodobne i jego pojawienie się wyjaśniamy odwołując się do przypadku. Jeśli jednak jest ono bardzo złożone i w konsekwencji niezwykle mało prawdopodobne, to (i tu znajdujemy oryginalny wkład Williama Dembskiego, twórcy filtra) pytamy, czy charakteryzuje je specyficzny, charakterystyczny dla inteligentnego działania, wzorzec. ${ }^{25}$ Dopiero gdy odpowiedź na ostatnie pytanie jest pozytywna, mamy prawo wnioskować o projekcie, czyli że wyjaśniane zjawisko powstało wskutek zamysłu rozumnej istoty.

Wniosek taki, oczywiście, jak każdy inny wniosek jest odwoływalny, zależy bowiem od kilku odpowiedzi na wcześniejsze pytania. Wystarczy, jeśli któraś z tych odpowiedzi zostanie zmieniona, by wniosek o projekcie był uznany za bezzasadny.

Koncepcja filtra eksplanacyjnego również została poddana drobiazgowej krytyce. ${ }^{26}$

Universe, Ignatius Press, San Francisco 2000, s. 31-40 [17-51]; William A. DemBski, ,Signs of Intelligence: A Primer on the Discernment of Intelligent Design”, w: William A. Dembski and James M. Kushiner (eds.), Signs of Intelligence. Understanding Intelligent Design, Brazos Press, Grand Rapids, MI 2003, s. 178-182 [171192]; William A. Dembski, No Free Lunch. Why Specified Complexity Cannot Be Purchased without Intelligence, Rowman \& Littlefield Publishers, Inc., Lanham - Boulder - New York - Oxford 2002, s. 12-15; William A. Dembski, „Reinstating Design within Science”, Rhetoric \& Public Affairs 1998, vol. 1, no. 4, s. 503-518, przedr. w: John Angus CAmpbell, Stephen C. Meyer (eds.), Darwinism, Design, and Public Education, Michigan State University Press, East Lansing 2003, s. 403-417; William A. Dembsкi, The Design Revolution. Answering the Toughest Questions about Intelligent Design, InterVarsity Press, Downers Grove, Illinois 2004, s. 87-93).

${ }^{25}$ Więcej na temat specyfikacji por. w: Kazimierz JoDKowski, „Rozpoznawanie genezy: istota sporu ewolucjonizm-kreacjonizm”, Roczniki Filozoficzne 2002, t. 50, z. 3, s. 195 [187198] (tam też czytelnik znajdzie kilka przykładów wnioskowania o projekcie należących niewątpliwie do nauki); Piotr BYLICA, „Testowalność teorii inteligentnego projektu”, Filozofia Nauki 2003, Rok 11, nr 2 (42), s. 44-46 [41-49].

${ }^{26}$ Por. Brandon Fitelson, Christopher STePhens and Elliott Sober, „How not to detect design - critical notice: William A. Dembski, The Design Inference", Philosophy of Science 1999, vol. 66, s. 472488 (przedruk w: Robert T. PENnock (ed.), Intelligent Design Creation- 


\section{c) Ewolucyjni kreacjoniści i teistyczni ewolucjoniści}

Scott nie podała przekonywującego powodu odróżniania obu tych obozów. Jedni i drudzy uważają, że ewolucja jest sposobem, jaki Bóg zastosował w swoim działaniu. Nie sprzeciwiają się więc oni danym naukowym czy to na temat wieku Wszechświata i Ziemi, czy świadczących o realności procesu ewolucyjnego. Uważają, że Bóg albo działa poprzez pierwotne stworzenie (Scott przy tej okazji wypowiada słuszną opinię, że tym samym są bliscy deizmu), albo od czasu do czasu interweniuje w przyrodzie, zwłaszcza jeśli chodzi o powstanie człowieka (wówczas ich stanowisko staje się bliskie progresywnym kreacjonistom). Jedyna różnica między ewolucyjnymi kreacjonistami i teistycznymi ewolucjonistami polega na tym, że ci pierwsi występują wśród konserwatywnych ewangelikalnych chrześcijan, a ci drudzy wśród liberalnych chrześcijan, np. katolików.

\section{d) Materialistyczni ewolucjoniści}

Zajmują oni stanowisko niereligijne tożsame $\mathrm{z}$ ewolucjonizmem naturalistycznym w klasyfikacji Ericksona. W opinii Scott nauka jest neutralna wobec religii. Działa ona stosując metodologiczny materializm (w literaturze częściej nazywany jest on metodologicznym naturalizmem), który ogranicza zakres wyjaśnień naukowych do wyjaśnień naturalistycznych, czyli poszukujących przyczyn wewnątrz świata. Materialistyczni ewolucjoniści idą krok dalej: twierdzą, że ża-

ism and Its Critics. Philosophical, Theological, and Scientific Perspectives, A Bradford Book, The MIT Press, Cambridge, Massachusetts - London, England 2001, s. 597-615); Robert T. Pennock, Tower of Babel. The Evidence against the New Creationism, A Bradford Book, The MIT Press, Cambridge, Massachusetts - London, England 1999 (third print ing 2002), s. 94-96; Massimo Pigliucci, „Design Yes, Intelligent No: A Critique of Intelligent Design Theory and Neo-Creationism", w: CAmpBell, MeYer (eds.), Darwinism..., s. 467-470 [463-473]; Larry Wiтнам, By Design. Science and the Search for God, Encounter Books, San Francisco 2003, s. 143-149; Mark Perakh, Unintelligent Design, Prometheus Books, Amherst, New York 2004, s. 87-88; Barbara Forrest \& Paul R. Gross, Creationism's Trojan Horse. The Wedge of Intelligent Design, Oxford University Press, Oxford - New York 2004, s. 114-146. 
den czynnik nadprzyrodzony nie istnieje, że przyroda i jej prawa są wszystkim, co jest.

\section{B. Wady klasyfikacji Scott-Wise'a}

Wady tej klasyfikacji są olbrzymie i dyskwalifikujące całą próbę.

Podstawowy zarzut dotyczy zasady podziału. Co znaczy „dosłowna interpretacja Biblii"? Prawdopodobnie chodzi o nieuwzględnianie stosowanych w każdym języku, także w starożytnym hebrajskim, narzędzi gramatycznych, wskazujących na intencję autora. Jeśli autor zamierzał oddać jakąś myśl w języku poetyckim, to jest oczywiste, że niedosłowne odczytanie jakiegoś fragmentu jest bardziej dosłowne, jeśli chodzi o jego intencje, niż tzw. dosłowne odczytanie.

Dobry przykład podała sama Scott. Wspomina ona o zwrotach „cztery kąty ziemi” oraz „okrąg ziemi”, które dosłownie mają rozumieć płaskoziemcy. Pierwszy z nich występuje np. w Obj. 7:1. Ale Księga Objawienia jest napisana w swoistym stylu literackim i przy pomocy języka symbolicznego. Wyraźnie stwierdza ona (Obj. 1:10 i 4:1-2), że stanowi zapis nadnaturalnego widzenia, co znaczy, że wydarzenia $w$ niej opisane należy rozumieć symbolicznie. We współczesnym języku polskim mówi się o wschodzie i zachodzie słońca, z czego nie można wnioskować, że ci, którzy tak mówią, przyjmują ideę nieruchomej Ziemi. Dosłowna interpretacja tekstu musi uwzględniać styl, intencje i kontekst historyczny. Jeśli wyimaginowani płaskoziemcy elementów tych nie uwzględniają, to oni właśnie proponują odczytanie niedosłowne, a nie ci, którzy interpretują takie teksty zgodnie $\mathrm{z}$ intencją autora. Patrząc $\mathrm{z}$ tego punktu widzenia idee płaskiej Ziemi należy umieścić niżej w klasyfikacji, gdzieś w pobliżu ewolucyjnego kreacjonizmu, czyli byłyby - wedle założenia Scott bardziej wiarygodne niż koncepcja młodej, a nawet starej Ziemi.

Pewne z dalszych zarzutów sygnalizowałem przy omawianiu koncepcji Scott-Wise'a. Płaskoziemcy nie istnieją dzisiaj jako poważnie głoszący swoje poglądy osoby, a rozróżnienie ewolucyjnych kreacjo- 
nistów i teistycznych ewolucjonistów polega jedynie na użyciu innych słów.

Wiele wątpliwości związanych jest z podziałem kreacjonizmu starej Ziemi na teorię luki czasowej, konkordyzm, progresywny kreacjonizm i teorię inteligentnego projektu. Nawet co do umieszczenia w tej kategorii teorii luki czasowej mogą się pojawić wątpliwości, jeśli uprzytomnimy sobie, ze zwolennicy tej „teorii” nie konkretyzują, jak długo trwała wspomniana luka - mogła trwać tydzień lub miesiąc, a to trudno uznać za podstawę zaliczenia tej koncepcji do staroziemskiej. Scott odróżnia konkordyzm i progresywny kreacjonizm, ale konkordyzm może być jednocześnie progresywnym kreacjonizmem - tak jest w przypadku podawanego przez samą Scott dra Hugh Rossa jako przykładu progresywnego kreacjonisty - jak i teistycznym ewolucjonizmem (ewolucyjnym kreacjonizmem).

Największe zastrzeżenia pojawiają się jednak w związku z zaliczeniem teorii inteligentnego projektu do kreacjonizmu starej Ziemi. Rzeczywiście, najczęściej zwolennicy teorii inteligentnego projektu akceptują przyjmowany w nauce wiek Wszechświata i Ziemi. Ale nie jest to wymóg tej teorii. Sprawa wieku Ziemi nie jest tematem, którym ta teoria się zajmuje. I rzeczywiście, wśród jej zwolenników można znaleźć na przykład kreacjonistów młodej Ziemi, jak Paul Nelson, ${ }^{27}$ ale i teistycznych ewolucjonistów, jak Michael J. Behe. ${ }^{28}$

Nie do zaakceptowania jest też założenie, że wszystkie rozważane stanowiska, w tym teorię inteligentnego projektu, można uszeregować pod względem ich stosunku do Biblii, stopnia literalności jej interpretacji. Wśród zwolenników teorii ID są nie tylko chrześcijanie, ale

\footnotetext{
${ }^{27}$ Por. Paul Nelson \& John Mark Reynolds, „Young Earth Creationism”, w: J.P. Moreland and John Mark Reynolds (eds.), Three Views on Creation and Evolution, Zondervan Publishing House, Grand Rapids, Michigan 1999, s. 39-75.

${ }^{28},[\ldots]$ uważam ideę wspólnoty pochodzenia (to, że wszystkie organizmy posiadają wspólnego przodka) za przekonującą i nie mam szczególnego powodu, by w nią wątpić" (Michael J. Bene, Darwin's Black Box. The Biochemical Challenge to Evolution, The Free Press, New York - London - Toronto - Sydney - Singapore 1999, s. 5).
} 
też żydzi, jak David Berlinski, ${ }^{29}$ muzułmanie, jak Harun Yahya, ${ }^{30}$ agnostycy, jak Michael Denton, ${ }^{31}$ czy nawet ateiści, jak raelianie, ${ }^{32}$ Francis Crick ${ }^{33}$ czy Fred Hoyle. ${ }^{34}$ Teorii inteligentnego projektu nie można zaklasyfikować jako wrogiej wobec ewolucjonizmu. Jej epistemiczny układ odniesienia obejmuje zarówno kreacjonizm, jak i ewolucjonizm. ${ }^{35}$ Dobrym przykładem tej cechy, czego nie rozumie wielu krytyków teorii ID, jest fakt, iż jej zwolennicy nie identyfikują projektanta, o którego istnieniu wnoszą, oraz uważają, że święte teksty nie mają $\mathrm{w}$ nauce autorytetu. Zbiór twierdzeń teorii inteligentnego projektu jest czymś w rodzaju „kartezjańskiego iloczynu” kilku różnych stanowisk, przy czym niektórzy zwolennicy ID wyraźnie wychodzą poza ten ,iloczyn”, a inni - nie.

\footnotetext{
${ }^{29}$ Por. David Berlinski, „On the Origin of Life”, Commentary February 2006, s. 22-33; TENżE, „A Scientific Scandal”, Commentary 2003, April 1; tenże, „Keeping an Eye on Evolution: Richard Dawkins, a relentless Darwinian spear carrier, trips over Mount Improbable" (Review of: Climbing Mount Improbable, by Richard Dawkins, W.H. Norton \& Company, Inc. 1996, 288 pages), The Globe \& Mail, November 2, 1996, p. D10; TENŻE, „The Deniable Darwin", Commentary 1996, June 1.

${ }^{30}$ Omówienie jego poglądów por. w moim artykule „Harun Yahya jako czołowy przedstawiciel islamskiego kreacjonizmu", Na Początku... wrzesień 2001, nr 9 (146), s. 269-274.

${ }^{31}$ Por. Michael J. Denton, Nature's Destiny. How the Laws of Biology Reveal Purpose in the Universe, The Free Press, New York - London - Toronto - Singapore - Sydney 1998.

${ }^{32}$ Por. „Raelian Movement supports ID Theory”, http://www.prweb.com/releases/2002/ 11/prweb50443.php

${ }^{33}$ Por. Francis H.C. CRick and Leslie E. Orgel, „Directed panspermia”, Icarus 1973, vol. 19, s. 341-346. Por. także Mieczysław PAJEwski, „Molibden, kierowana panspermia i ostateczny ratunek przed kreacjonizmem”, Na Początku... marzec-kwiecień 2002, nr 3-4 (153-154), s. $82-86$.

${ }^{34}$ Omówienie jego poglądów por. w moim artykule „Fred Hoyle (1915-2001)”, w: Fred HoyLe, Matematyka ewolucji, Wyd. MEGAS, Warszawa 2003, s. 21-36.

${ }^{35}$ Por. Kazimierz JoDKowski, „Epistemiczny układ odniesienia teorii inteligentnego projektu”, Filozofia Nauki 2006, nr 1 (53), s. 95-105.
} 


\section{Marcusa R. Rossa zagnieżdżona hierarchia projektu}

Tak rażących błędów nie ma propozycja Marcusa R. Rossa, ${ }^{36}$ aby stanowiska dotyczące pochodzenia sklasyfikować według siedmiu różnych cech (przy czym niektóre $\mathrm{z}$ tych cech nie stosują się do niektórych stanowisk):

A - realne istnienie (lub nieistnienie) projektu w świecie przyrodniczym

B - empiryczna wykrywalność (lub niewykrywalność) projektu

C - cielesność (lub niecielesność) projektanta

D - immanentność (lub transcendentność) projektanta wobec świata

E - deistyczny (lub teistyczny) charakter aktywności projektanta

F - ciągłość (albo nieciągłość) linii rodowych organizmów

$\mathrm{G}$ - wielomiliardoletni (albo kilkutysiącletni) wiek Ziemi

\section{A. Stanowiska}

Zastosowanie tych cech pozwoliło Rossowi wyróżnić 8 teleologicznych stanowisk i jedno nieteleologiczne:

materialistyczny ewolucjonizm

„słaby” deistyczny ewolucjonizm

„słaby” teistyczny ewolucjonizm

\footnotetext{
${ }^{36}$ Por. Marcus R. Ross, „Who Believes What? Clearing up Confusion over Intelligent Design and Young-Earth Creationism", Journal of Geoscience Education May 2005, vol. 53, no. 3, s. 319-323 oraz Marcus Ross and Paul Nelson, „A Taxonomy of Teleology”, w: William A. Dembsкi (ed.), Darwin's Nemesis. Phillip Johnson and the Intelligent Design Movement, Inter-Varsity Press, Leicester, England 2006, s. 272-275 [261-275].
} 
teoria cielesnego projektanta

teoria wewnętrznego projektu

„mocny” deistyczny ewolucjonizm

„mocny” teistyczny ewolucjonizm

kreacjonizm starej Ziemi

kreacjonizm młodej Ziemi

a) Materialistyczny ewolucjonizm - w świecie ożywionym i nieożywionym istnieją jedynie pozory projektu. Przyczynami są jedynie procesy naturalne.

b) „Słaby” ewolucjonizm deistyczny - projekt istnieje, ale jest empirycznie niewykrywalny. Bóg działał tylko w okresie początkowym. Zróżnicowanie świata ożywionego jest rezultatem jedynie działania procesów przyrodniczych.

c) „Słaby” teistyczny ewolucjonizm - projekt istnieje zarówno w dziedzinie nieożywionej, jak i ożywionej, ale jest empirycznie niewykrywalny. Bóg działał nie tylko w okresie pierwotnym, ale i później, projektując biologiczne zróżnicowanie przy pomocy uniwersalnej wspólnoty pochodzenia w ciągu ubiegłych 4,5 miliarda lat.

d) Teoria cielesnego projektanta - w świecie ożywionym istnieje projekt i można go empirycznie wykrywać. Projektantem są istoty fizyczne, które zaprojektowały w ciągu ubiegłych 4,5 miliarda lat złożoność biologiczną, realizowaną poprzez wspólnotę pochodzenia. Przykłady to teoria kierowanej panspermii (Crick) czy raelianizm.

e) Teoria wewnętrznego projektu - w świecie nieożywionym lub/i w świecie ożywionym istnieje projekt i można go empirycznie wykrywać. Projektantem jest istota złączona albo nawet tożsama $\mathrm{z}$ Wszechświatem, działająca przyczynowo od początku, projektująca przez 4,5 miliarda lat biologiczne zróżnicowanie przez uniwersalną wspólnotę pochodzenia. 
f) „Mocny” deistyczny ewolucjonizm - w świecie nieożywionym i ożywionym istnieje projekt i można go empirycznie wykrywać. Jest on rezultatem działania transcendentnej Istoty Boskiej działającej tylko w początkowym okresie. Procesy przyrodnicze są jedynymi czynnikami, które doprowadziły do powstania różnorodności biologicznej w ciągu ostatnich 4,5 miliarda lat.

g) „Mocny” teistyczny ewolucjonizm - w świecie nieożywionym i ożywionym istnieje projekt i można go empirycznie wykrywać. Jest on rezultatem działania transcendentnej Istoty Boskiej, działającej zarówno w okresie początkowym, jak i później. Działania te doprowadziły w ciągu 4,5 miliarda lat do powstania biologicznej różnorodności powiązanej uniwersalną wspólnotą pochodzenia.

h) Kreacjonizm starej Ziemi - w świecie nieożywionym i ożywionym istnieje projekt i można go empirycznie wykrywać. Jest on rezultatem działania transcendentnej Istoty Boskiej, działającej zarówno w okresie początkowym, jak i później. Działania te doprowadziły w ciągu 4,5 miliarda lat do powstania nieciągłej biologicznej różnorodności.

i) Kreacjonizm młodej Ziemi - w świecie nieożywionym i ożywionym istnieje projekt i można go empirycznie wykrywać. Jest on rezultatem działania transcendentnej Istoty Boskiej, działającej zarówno w okresie początkowym, jak i później. Działania te doprowadziły w ciągu 6000 lat do powstania nieciągłej biologicznej różnorodności.

Wśród tych stanowisk Marcus R. Ross nie umieścił teorii inteligentnego projektu, gdyż uznał, że teoria ta jest terenem, co do którego zgadzają się różne stanowiska, od teorii cielesnego projektu do kreacjonizmu młodej Ziemi, wypowiadające oprócz tego wiele innych szczegółowych i niezgodnych wzajemnie twierdzeń.

\section{B. Wady klasyfikacji Marcusa R. Rossa}

Klasyfikacja ta niewątpliwie trafnie ujmuje relację między teorią inteligentnego projektu a wieloma innymi stanowiskami. Pokazuje 
także, że podział stanowisk kreacjonistycznych nie przebiega według przeciwnie skierowanych sympatii do Biblii i do nauki. Ma jednak także poważne wady.

Pierwsza polega na pewnym stopniu abstrakcyjności wymienionych stanowisk. Nie zawsze jest pewne, czy niektóre z nich są „obstawione” przez realnie istniejących myślicieli, a jeśli są - to przez kogo? Na przykład kto jest przedstawicielem słabego i mocnego deistycznego ewolucjonizmu? Kogo można zaliczyć do teorii wewnętrznego projektu? Panteistów? Panenteistów?

Druga wada to pominięcie w tej klasyfikacji kilku realnie występujących odmian kreacjonizmu. Nie uwzględniono w niej kreacjonizmu biblijnego. Nie ma też kreacjonizmu religijnego ani filozoficznego.

W związku z tym wydaje się, że najlepszą jak dotąd klasyfikację (a raczej: najlepsze klasyfikacje) przedstawiłem w swojej monografii $\mathrm{z}$ 1998 roku.

\section{Klasyfikacje Kazimierza Jodkowskiego}

Poniżej przedstawię skrótowo trzy klasyfikacje, nieco zmodyfikowane w porównaniu z ich postacią z 1998 roku. ${ }^{37}$ Pierwsza z nich dotyczy kreacjonizmu biblijnego i naukowego oraz ewolucjonizmu, druga została przeprowadzona z punktu widzenia zapisu kopalnego, a trzecia jest schematem klasyfikacyjnym wszystkich odmian kreacjonizmu.

\footnotetext{
${ }^{37}$ Por. Kazimierz JoDкоwsкi, Metodologiczne aspekty kontrowersji ewolucjonizm-kreacjonizm, Realizm. Racjonalność. Relatywizm t. 35, Wydawnictwo UMCS, Lublin 1998, s. 106-110.
} 


\section{STANOWISKA W SPORZE EWOLUCJONIZM-KREACJONIZM}

1. Kreacjonizm - Wszechświat, życie i człowiek są wynikiem specjalnych aktów stwórczych.

1.1. Kreacjonizm naukowy (przyrodniczy) - Wszechświat, życie i człowiek są wynikiem specjalnych aktów stwórczych i fakt ten można uzasadniać w sposób właściwy dla nauk przyrodniczych.

1.1.1. Kreacjonizm naukowy młodej Ziemi (Wszechświata) Wszechświat, życie i człowiek są wynikiem specjalnych aktów stwórczych ex nihilo, które miały miejsce raczej kilka tysięcy niż kilka miliardów lat temu.

1.1.1.1. Kreacjonizm naukowy młodej Ziemi (Wszechświata) empirycznie rozpoznawalny - Wszechświat, życie i człowiek są wynikiem specjalnych aktów stwórczych ex nihilo, które miały miejsce raczej kilka tysięcy niż kilka miliardów lat temu. Chociaż nieco pozornego wieku może istnieć (np. światło od gwiazd stworzone „W biegu"), to pomiary naukowe mogą dostarczyć argumentów, że Ziemia i życie są młode.

1.1.1.2. Kreacjonizm naukowy młodej Ziemi (Wszechświata) z pozorem wieku - Wszechświat, życie i człowiek są wynikiem specjalnych aktów stwórczych ex nihilo, które miały miejsce raczej kilka tysięcy niż kilka miliardów lat temu. Jednak stworzenie posiada cechy świadczące o jego starym wieku.

1.1.1.2.1. Kreacjonizm naukowy młodej Ziemi (Wszechświata) ze stworzonym pozorem wieku - Wszechświat, życie i człowiek są wynikiem specjalnych aktów stwórczych ex nihilo, które miały miejsce raczej kilka tysięcy niż kilka miliardów lat temu. Jednak stworzeniu nadano cechy świadczące o jego starym wieku.

1.1.1.2.2. Kreacjonizm młodej Ziemi (Wszechświata) $\mathrm{z}$ pozorem wieku wskutek radykalnej zmiany praw przyrody w przeszłości - 
Wszechświat, życie i człowiek są wynikiem specjalnych aktów stwórczych ex nihilo, które miały miejsce raczej kilka tysięcy niż kilka miliardów lat temu. Jednak w pewnej chwili w przeszłości Ziemia (i Wszechświat) zaczęła się starzeć wskutek radykalnej zmiany praw obowiązujących w przyrodzie (zaczęła obowiązywać zasada wzrostu entropii).

1.1.2. Kreacjonizm naukowy starej Ziemi (Wszechświata) Wszechświat, życie i człowiek są wynikiem specjalnych aktów stwórczych, które miały miejsce setki milionów lub miliardy lat temu i fakt ten można uzasadniać w sposób właściwy dla nauk przyrodniczych.

\subsubsection{Kreacjonizm starej Ziemi (Wszechświata) typu fiat -} Wszechświat, życie i człowiek są wynikiem specjalnych aktów stwórczych ex nihilo, które miały miejsce setki milionów lub miliardy lat temu.

1.1.2.2. Kreacjonizm starej Ziemi (Wszechświata) progresywny Wszechświat, życie i człowiek są wynikiem specjalnych aktów stwórczych, które miały miejsce setki milionów lub miliardy lat temu i polegały na względnie radykalnej modyfikacji już istniejących form życia tworząc nowe cechy i zwiększając złożoność życia.

\subsubsection{Kreacjonizm starej Ziemi (Wszechświata) mieszany co do}

formy stworzenia (progresywny i typu fiat) - Wszechświat, życie i człowiek są wynikiem specjalnych aktów stwórczych, które miały miejsce setki milionów lub miliardy lat temu i miały charakter fiat lub polegały na względnie radykalnej modyfikacji już istniejących form tworząc nowe cechy i zwiększając złożoność życia.

1.2. Kreacjonizm biblijny - Wszechświat, życie i człowiek są wynikiem specjalnych aktów stwórczych i fakt ten można uzasadniać w sposób właściwy dla nauk teologicznych (biblistyki).

1.2.1. Kreacjonizm biblijny młodej Ziemi (Wszechświata) - ujęcie stworzenia z Księgi Rodzaju 1-2 jest dosłownie prawdziwe, a stworzenie zaszło w nieodległej przeszłości (od kilku do ok. 10000 lat temu). 
1.2.1.1. Kreacjonizm biblijny młodej Ziemi (Wszechświata) z pozorem starego wieku - ujęcie stworzenia z Księgi Rodzaju 1-2 jest dosłownie prawdziwe, stworzenie zaszło w nieodległej przeszłości (od kilku do ok. 10000 lat temu), ale wskutek Upadku człowieka i/lub Szatana ma pozór starego wieku.

1.2.2. Kreacjonizm biblijny starej Ziemi (Wszechświata) - stworzony Wszechświat (i/lub Ziemia) liczy sobie znacznie więcej lat, niż by to wynikało ze zwykłego zsumowania biblijnych chronologii.

1.2.2.1. Kreacjonizm biblijny starej Ziemi (Wszechświata) z dosłownym rozumieniem dni stworzenia - Ziemia jest stara, ale dni z tygodnia stworzenia należy rozumieć dosłownie

1.2.2.1.1. Kreacjonizm biblijny starej Ziemi (Wszechświata) z dosłownym rozumieniem dni stworzenia, które jednak miały miejsce niedawno - odróżnia się stworzenie materii nieożywionej od kształtowania oblicza Ziemi i stworzenia życia, które zaszło niedawno.

1.2.2.1.2. Teoria przerwy czasowej - Wszechświat, Ziemia i życie zostały stworzone dawno temu, ale to pierwotne stworzenie zostało zniszczone, a następnie odtworzone kilka tysięcy lat temu w czasie dosłownie rozumianych 6 dni.

1.2.2.1.3. Kreacjonizm biblijny starej Ziemi (Wszechświata) z dosłownie rozumianymi dniami stworzenia oddzielonymi często bardzo długimi okresami czasu - biblijne dni stworzenia były jedynie pierwszymi dniami nowych faz w historii Wszechświata.

1.2.2.2. Kreacjonizm biblijny starej Ziemi (Wszechświata) z niedosłownym rozumieniem dni stworzenia - Ziemia jest stara, a tydzień stworzenia należy rozumieć metaforycznie.

1.2.2.2.1. Kreacjonizm biblijny starej Ziemi (Wszechświata) $\mathbf{z}$ utożsamieniem dni stworzenia $z$ epokami geologicznymi - tydzień stworzenia należy rozumieć metaforycznie jako całą historię stwo- 
rzenia; poszczególne dni z tygodnia stworzenia odpowiadają kolejnym epokom w dziejach stworzenia (konkordyzm).

1.2.2.2.2. Kreacjonizm biblijny starej Ziemi (Wszechświata) z utożsamieniem dni stworzenia $z$ dniami objawienia - Ziemia jest stara, a tzw. dni stworzenia są w rzeczywistości dniami, w których Bóg objawił Mojżeszowi, jak stwarzał świat.

1.2.2.2.3. Kreacjonizm biblijny starej Ziemi (Wszechświata) $\mathrm{z}$ utożsamieniem dni stworzenia $z$ dniami, w których Bóg wyrzekł swoje „niech się tak stanie" - Ziemia jest stara, ale dni stworzenia to tylko dni, w których Bóg wypowiedział swoje rozkazy (realizowane dopiero po pewnym czasie).

1.2.2.2.4. Kreacjonizm biblijny starej Ziemi (Wszechświata) rezygnujący z uzgodnienia jakiegokolwiek rozumienia dni stworzenia ze współczesną nauką.

2. Ewolucjonizm - (co najmniej) życie powstało i rozwinęło się na drodze ewolucyjnej. Różne formy życia powiązane są wspólnotą pochodzenia.

2.1. Ewolucjonizm teistyczny - życie powstało i rozwinęło się na drodze ewolucyjnej, a ewolucja jest Bożym sposobem stwarzania.

2.1.1. Ewolucjonizm teistyczny $\mathbf{z}$ ewolucją kierowaną - stworzenie nastąpiło poprzez ewolucję, ale jej sukces jest niespodziewany, co znaczy, że nie można było oczekiwać, że będzie tak pomyślna. A była tak pomyślna, gdyż Bóg w jakiś sposób kierował procesem ewolucyjnym, by zachodził wedle wcześniej ustalonych dróg, prowadząc do dużo lepszych wyników, niż można by oczekiwać bez tego kierowania.

2.1.2. Ewolucjonizm teistyczny ze stworzeniem pierwszego życia nie ma niczego zaskakującego w rezultatach ewolucji (nie musiała być kierowana), zaskakujące jest jedynie to, że się rozpoczęła. Początek życia jest wynikiem aktywności Boga, po czym same procesy ewo- 
lucyjne doprowadziły do obserwowanego dzisiaj zróżnicowania życia (pogląd przypisywany czasami niesłusznie Darwinowi).

2.1.3. Ewolucjonizm teistyczny naturalistyczny - nie ma niczego zaskakującego ani w rezultatach ewolucji, ani w tym, że się kiedyś rozpoczęła. Wszystko, co się stało, jest wynikiem obowiązujących praw przyrody. Zaskakujące jest jedynie dopasowanie tych praw oraz rozmaitych stałych fizycznych do pojawienia się życia i wyewoluowania człowieka (zasada antropiczna).

\subsubsection{Ewolucjonizm teistyczny naturalistyczny $\mathbf{z}$ wyznaczonym} wcześniej celem - procesy ewolucyjne mają naturalistyczny charakter, ale prawa przyrody i stałe fizyczne zostały tak dobrane, by po wielu miliardach lat doprowadzić do tego, co dzisiaj obserwujemy.

2.1.3.2. Ewolucjonizm teistyczny naturalistyczny bez wyznaczonego wcześniej celu - zarówno powstanie życia, jak i dalsze procesy ewolucyjne zachodziły bez interwencji Boga, a rezultaty ewolucji nie były do końca wstępnie określone przez Niego; dał On raczej stworzeniu pewien stopień „wolności”. Bóg jedynie wiedział, że proces ten w końcu doprowadzi do pojawienia się rozumnych osób, którym będzie się mógł Objawić.

2.2. Ewolucjonizm deistyczny - Bóg stworzył Wszechświat i prawa przyrody, ,puścił je w ruch” i pozwolił, by całość się rozwijała bez żadnej interwencji z Jego strony.

2.3. Ewolucjonizm panteistyczny - Ziemia, a może nawet i cały Wszechświat, jest jednym żywym organizmem, której przysługują pewne cechy boskie (należy ją szanować, dbać o nią, urządzać święta, zgromadzenia itp.).

2.4. Ewolucjonizm ateistyczny - Wszechświat istnieje samoistnie i odwiecznie, albo jeśli powstał, to bez żadnej przyczyny. Nie ma żadnego Stwórcy. 
NaJWAŻNiEJSZE STANOWISKa

\section{W SPORZE EWOLUCJONIZM-KREACJONIZM}

(z punktu widzenia zapisu kopalnego)

\begin{tabular}{|c|c|}
\hline $\begin{array}{l}\text { Dane kopal- } \\
\text { ne są upo- } \\
\text { rządkowane }\end{array}$ & $\begin{array}{l}\text { Dane kopalne nie są uporządkowane - kolumna geologicz- } \\
\text { na jest papierową fikcją i nigdzie w rzeczywistości nie } \\
\text { istnieje - agnostyczni kreacjoniści }\end{array}$ \\
\hline$\downarrow$ & \\
\hline $\begin{array}{l}\text { Porządek } \\
\text { ten świad- } \\
\text { czy o suk- } \\
\text { cesji czaso- } \\
\text { wej }\end{array}$ & $\begin{array}{l}\text { Porządek skamieniałości jest rezultatem Potopu i za- } \\
\text { mieszkiwania przez zwierzęta odmiennych stref ekolo- } \\
\text { gicznych - ,geologowie” Potopu (kreacjoniści młodej } \\
\text { Ziemi, zwolennicy teorii przerwy czasowej na temat } \\
\text { świata po-Adamowego }\end{array}$ \\
\hline
\end{tabular}

$\downarrow$

Sukcesja czasowa jest rezultatem ewolucji

Sukcesja jest wynikiem kolejnych aktów stwórczych - kreacjoniści starej Ziemi, zwolennicy teorii przerwy czasowej na temat świata przedAdamowego

$\downarrow$

Jedynym dogodnym wyjaśnieniem ewolucji jest darwinizm

Darwinizm nie jest jedynym dogodnym wyjaśnieniem ewolucji - niedarwinowscy ewolucjoniści

$\downarrow$

Za ewolucję odpowiedzialne są wyłącznie ,ślepe" siły przyrody ateistyczni ewolucjoniści

Ewolucja jest metodą stosowaną przez Boga przy stwarzaniu żywych organizmów teistyczni ewolucjoniści 
KLASYFIKACJa POSTAW KREACJONISTYCZNYCH (SCHEMAT)

\section{Kreacjonizm}

- $\quad$ religijny (fragment doktryny religijnej)

- metafizyczny

- naukowy (w „polskim” sensie tego słowa)

- biblijny (ponieważ chodzi o naukę dotyczącą Biblii, właściwszym określeniem byłoby może „biblistyczny”)

- przyrodniczy (naukowy w, ,angielskim sensie tego słowa)

- kreacjonizm naukowy w szerokim sensie (teistyczny ewolucjonizm)

- teistyczny ewolucjonizm prowidencjalny (God of the gaps)

- teistyczny ewolucjonizm naturalistyczny

- $\quad$ kreacjonizm naukowy w wąskim, właściwym sensie

- w sprawie wieku życia na Ziemi

- $\quad$ kreacjonizm mlodej Ziemi

- $\quad$ kreacjonizm starej Ziemi

- w sprawie sposobu stwarzania

- $\quad$ kreacjonizm typu fiat

- $\quad$ kreacjonizm progresywny

- $\quad$ stanowisko łączące elementy obu powyższych

- w sprawie zapisu kopalnego

- $\quad$ kreacjonizm progresywny

- $\quad$ kreacjonizm agnostyczny

- geologia Potopu 
Po bliższe eksplikacje wymienionych stanowisk, ze względu na ograniczoną objętość prezentowanego artykułu odsyłam do mojej najnowszej monografii. ${ }^{38}$

Kazimierz Jodkowski

${ }^{38}$ Kazimierz Jodкоwski, Spór ewolucjonizmu z kreacjonizmem. Podstawowe pojęcia i poglądy, Wyd. Megas, Warszawa 2007. 